\title{
Table of treaties and regulations
}

\section{TREATIES}

EC Treaty (Treaty of Rome, as amended) [1957] 298 UNTS 11.

Treaty Articles as renumbered by the Treaty of Amsterdam (EC Treaty) [1997] OJ C340/1

Article $81 \quad 3, \mathbf{1 7}, \mathbf{2 0}, \mathbf{3 8}, \mathbf{8 9}, \mathbf{9 0}, \mathbf{9 3}$, 130, 182

Article 81(1) 17, 38, 89, 90

Article 81(3) 38, 89, 93, 95

Article 82 6, 7, 10, 17, 18, 20, 22,

$23,24,27,29,31,33,34,36,38$, $39,51,52,53,54,82,83,85,86$, $87,88,89,90,91,92,93,94,95$, 96, 97, 98, 99, 100, 102, 103, 104, 105, 106, 108, 130, 131, 132, 133, 134, 135, 136, 137, 139, 140, 141, 142, 143, 144, $145,152,153,154,155,156$, $157,161,182$

Article $230 \quad \mathbf{1 4 3}$

Article $234 \quad 20$

Convention for the protection of Human Rights and Fundamental Freedoms (European Convention on Human Rights, as amended) [1950] 213 UNTS 220

Article 6 144, 145

\section{REGULATIONS}

\section{European Council}

Council Regulation (EEC) 17/62 First regulation implementing Articles 85 and 86 [now Articles 81 and 82] of the Treaty [1962] OJ Spec Ed 87 as amended [1999] OJ C148/5 38, 39, 130, 144

Council Regulation (EC) 4056/86 Application of the competition rules to maritime transport [1986] OJ L378/4 93

Council Regulation (EC) No 1/2003 of 16 December 2002 on the implementation of the rules of competition laid down in Articles 81 and 82 of the Treaty [2003] OJ L1/1 20, 38, 39, 130, 132

Council Regulation (EC) No

139/2004 of 20 January 2004 on the control of concentrations between undertakings (the EC Merger Regulation) [2004] OJ L24/1 6, 19, 23, 31, 32, 108

\section{European Commission}

Commission Regulation (EC) No 773/2004 of 7 April 2004 relating to the conduct of proceedings by the Commission pursuant to Articles 81 and 82 of the EC Treaty [2004] OJ L123/18 $\mathbf{1 3 0}$ 


\section{NOTICES}

\section{European Commission}

Commission Notice on the application of the competition rules to access agreements in the telecommunications sector [1998] OJ C 265/02 29

Commission Notice on the appraisal of horizontal mergers under the Council Regulation on the control of concentrations between undertakings [2002] COM (2002) 29, 46, 52, 174

Commission Notice on the handling of complaints by the Commission under Articles 81 and 82 of the EC Treaty [2004] OJ C 101/65 130

\section{GREEN PAPERS,} GUIDELINES AND WORKING DOCUMENTS

\section{European Commission}

Commission Green Paper on the Review of Council Regulation (EEC) No 4064/89 [2001] COM (2001) $745 / 6 \quad \mathbf{5 2 , ~ 1 1 5 , ~} 162$

Commission Working Document On

Proposed New Regulatory

Framework for Electronic

Communications Networks and Services - Draft Guidelines on market analysis and the calculation of significant market power under Article 14 of the proposed Directive on a common regulatory framework for electronic communications networks and services [2001] COM (2001) 175 9, 19, 29

Commission guidelines on the assessment of horizontal mergers under the Council Regulation on the control of concentrations between undertakings [2004] OJ C $31 / 5 \quad 8,19,30,169$

Commission staff working document - Accompanying the Communication from the Commission - Sector Inquiry under Article 17 of Regulation (EC) No $1 / 2003$ on retail banking (Final Report) COM(2007) (31 January 2007) 132

Commission Guidelines on the assessment of non-horizontal mergers under the Council Regulation on the control of concentrations between undertakings [2008] OJ C 2659

Commission of the European

Communities 'Guidance on the Commission's Enforcement Priorities in Applying Article 82 EC Treaty to Abusive Exclusionary Conduct by Dominant Undertakings' [2008] (COM) 3 December $2008 \quad 6$, 133 